Jurnal Ilmu Komputer dan Informasi (Journal of a Science and Information). 12/1 (2019), 51-56

DOI: http://dx:doi:org/10:21609/jiki:v12i1:695

\title{
DETECTION OF DISEASE ON CORN PLANTS USING CONVOLUTIONAL NEURAL NETWORK METHODS
}

\author{
Ardi Hidayat, Ucuk Darusalam, Irmawati \\ Faculty of Communication and Information Technology, National University, South Jakarta, Indonesia \\ E-mail: ardihidayat136@gmail.com
}

\begin{abstract}
Deep Learning is still an interesting issue and is still widely studied. In this study Deep Learning was used for the diagnosis of corn plant disease using the Convolutional Neural Network (CNN) method, with a total dataset of 3.854 images of diseases in corn plants, which consisted of three types of corn diseases namely Common Rust, Gray Leaf Spot, and Northern Leaf Blight. With an accuracy of 99\%, in detecting disease in corn plants.
\end{abstract}

Keywords: Convolutional Neural Network, Deep Learning, Corn Plants

\begin{abstract}
Abstrak
Deep Learning masih menjadi isu yang menarik dan secara luas masih diteliti. Pada penelitian ini Deep Learning digunakan untuk proses diagnosa penyakit tanaman jagung menggunakan metode Convolutional Neural Network (CNN), dengan jumlah dataset sebanyak 3.854 gambar penyakit pada tanaman jagung, yang terdiri dari tiga jenis penyakit jagung yaitu Common Rust, Gray Leaf Spot, dan Northern Leaf Blight. Dengan hasil akurasi sebesar 99\%, dalam mendeteksi penyakit pada tanaman jagung.
\end{abstract}

Kata Kunci: Convolutional Neural Network, Deep Learning, Tanaman Jagung.

\section{Introduction}

Indonesia is one country that has great potential in agriculture. However, there are often many losses in the crop due to disease in plants, one of which occurs in corn plants. Diseases in plants before reaching a more severe and widespread stage generally begin by showing symptoms of the disease in a mild and still a little stage [1].

Deep Learning is a science branch of Machine Learning based on artificial neural networks that teaches computers to perform actions that are considered natural by humans. In Deep Learning, a computer learns to classify directly from images, text or sound [2]

Along with the development of technology, digital image classification is needed in various fields of informatics, medicine, marine, agriculture, and business. Some research that has been done in the field of agriculture is the detection of diseases in plants[1]. As in corn [3], rice [4], flowers [5], vegetables [6], cucumbers [7], and tomatoes [8].

With the problems faced by farmers in diagnosing maize disease, a system is needed to make it easier for farmers to diagnose maize disease. method used in disease identification in corn plants is by using the Convolutional Neural Network (CNN) method, this method can be used to identify diseases in corn plants[9]. The problems to be discussed in this study include the following: Implementing the Convolutional Neural Network method for detection of diseases in corn plants. What is the level of accuracy of the Convolutional Neural Network model used.

In connection with the large extent of the discussion in the problems found in this study, the boundaries of the problem will be made. Limitations of the problems to be addressed are: This study implements the Convolutional Neural Network method as a basis for detection of disease in corn plants. The data used in this study are leaf disease data on corn plants.

The objectives to be achieved in the study of disease detection in corn plants using the Convolutional Neural Network method are: Implementation the Convolutional Neural Network method for detection of diseases in corn plants. Solve problems in detecting diseases in corn plants using a mobile application. 


\section{Jurnal Ilmu Komputer dan Informasi (Journal of Computer Science and Information),}

volume 12, issue 1, February 2019

\section{Methods \\ Research Framework}

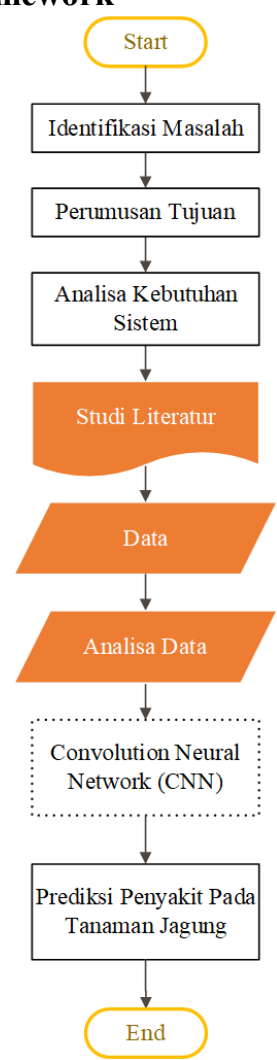

Figure 1. Research Framework

Figure 1. Describe the research framework. The flowchart of the research framework begins with the stage of problem formulation and the purpose of problem solving. The next step is analysis of system requirements and literature studies as a reference for research on corn plant disease detection using the Convolutional Neural Network method. In the early stages of the study, collect a dataset of disease images on corn plants, than data in the analyst. The next step is to design a Convolutional Neural Network model, after the CNN model, the final results obtained are predictions of disease in corn plants.

\section{Convolutional Neural Network}

Convolutional Neural Network (CNN) is one of the algorithms from Deep Learning which is the development of Multi Layer Perceptron (MLP) which is designed to process data, one of which is two-dimensional image data, for example images. Convolutional Neural Network is used to classify labeled data using the supervised learning method, which is how the supervised learning method works is that there is data that is trained and there are targeted variables [1].

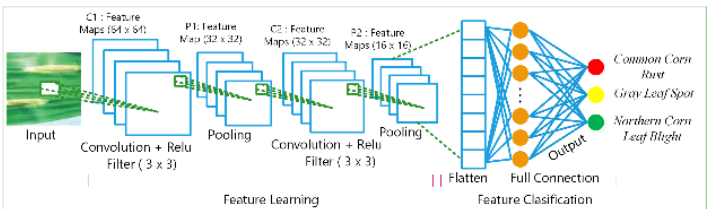

Figure 2. It is a Convolutional Neural Network model, which has two learning features and classification features. In the first stage, input image data is than entered into the learning stage which has two stages of convolution. In the first convolution stage, convolution is than carried out and activated ReLu, than the pooling stage is performed. In the second stage of convolution, the first convolution stage is completed, followed by convolution, than activation ReLu, than the pooling stage is performed. While the classification feature is flattening, than full connection, than the last step is at the output layer.

\section{Dataset}

In this study the dataset was obtained from PlantVillage with 50,000 images of various types of plants. This study uses a dataset of maize disease images with a number of datasets of 3,854 with three types of maize diseases, namely: Common Rust, Gray Leaf Spot, dan Northern Leaf Blight.

Training data is data that is used to make the system learn the features that exist in the image and classify these features. and testing data is data used to test the accuracy of the classification results of training data features.

TABLE 1

CORN PLANT DISEASE

\begin{tabular}{l} 
Picture of the Disease \\
$\begin{array}{l}\text { Common Rust, Symptoms that } \\
\text { are experienced by small patches } \\
\text { are round until the oval is found } \\
\text { on the leaf surface at the top and } \\
\text { bottom. }\end{array}$ \\
$\begin{array}{l}\text { Gray Leaf Spot, Symptoms } \\
\text { experienced by com plants } \\
\text { attacked by blight in the form of } \\
\text { gray brown spots on the entire } \\
\text { leaf surface. } \\
\text { Northern Leaf Blight. The } \\
\text { symptoms are small, oval-shaped } \\
\text { spots, than the more elongated } \\
\text { spots are elliptical in color gray or } \\
\text { brown. }\end{array}$ \\
\\
\hline
\end{tabular}




\section{Convolutional Layer}

Convolutional layers are a major part of the CNN architecture. This stage performs a convolution operation on the output of other functions repeatedly. Convolution operations apply the output function as a Feature Map from the image.

The purpose of convolution in image data is to extract features from the input image. Convolution will produce linear transformations of input data according to spatial information on the data. The weight on that layer specifies which convolution kernel is used, so that convolution kernels can be trained based on input on CNN.

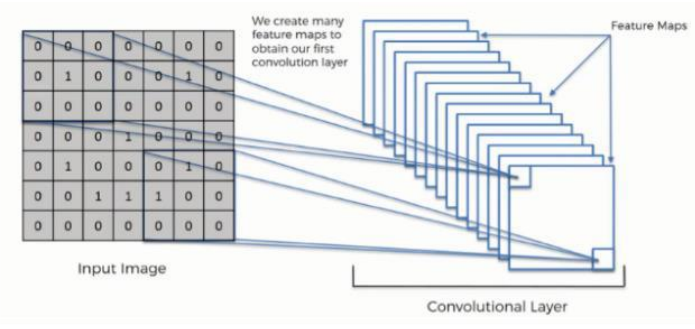

Figure 3. Convolution Layer

\section{Activation Function}

The activation function used is the Rectified Linear Unit (ReLu). The size of the kernel or filter used for each convolution layer is $3 \times 3$ with the aim of speeding up the training process and increasing the accuracy of identification.

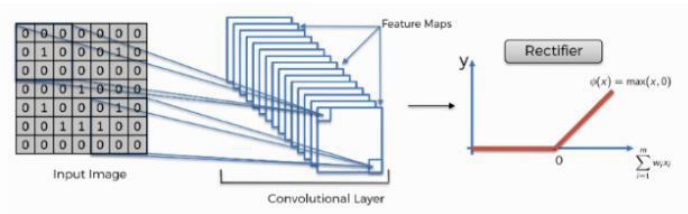

Figure 4. Rectified Linear Unit (ReLu)

\section{Pooling}

Pooling is a process that reduces the spatial size of a feature map or from the results of the convolution is than used as input to produce a feature representation. This gives CNN the ability to recognize an object. Pooling layer is used to take the maximum value (max-pooling) or the average value of the pixel parts in the image. The pooling method that is often used in $\mathrm{CNN}$ is the maxpooling method.

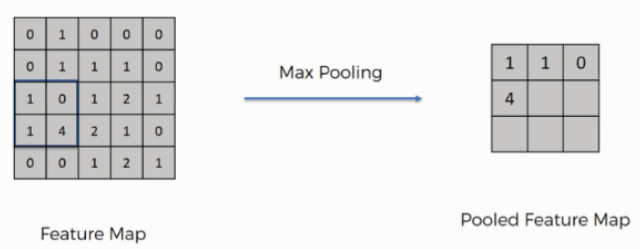

Figure 5. Max-Pooling

\section{Flattening}

After the pooling stage is complete, the flattening stage will be carried out or level the results from pooling into the fully connected layer. as shown in Figure 6.

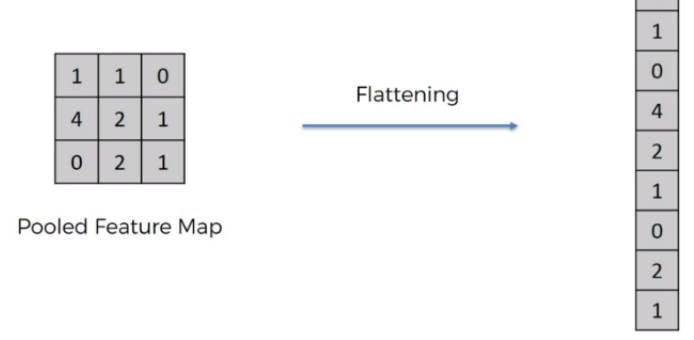

Figure 6. Flattening

\section{Full Connection}

A full connected layer is a layer where all activation neurons from the previous layer are all connected with neurons in the next layer. Each activation of the previous layer needs to be converted into one-dimensional data before it can be connected to all neurons in the fully-connected layer.

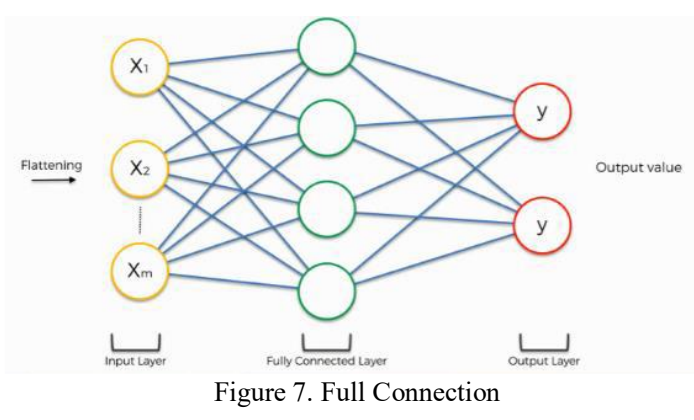

\section{Output}

After the feature training and feature classification process is complete, the last layer is the output layer, in the output layer there are three types of diseases in corn plants, namely Common Rust, Gray Leaf Spot, and Northern Leaf Blight. 


\section{Jurnal Ilmu Komputer dan Informasi (Journal of Computer Science and Information),}

volume 12, issue 1, February 2019

\section{Results and Discussion}

\section{Hardware and Software Specifications}

In this detection study using hardware and software devices. Some hardware devices used in this study are shown in Table 2, and the software used is shown in Table 3.

TABLE 2

SPECIFICATION HARDWARE

\begin{tabular}{ll}
\multicolumn{1}{c}{ Name } & \multicolumn{1}{c}{ Descriptions } \\
\hline CPU & Intel Core i7-8700 CPU@3.20GHz \\
\hline GPU & NVIDIA Geforce GTX1050 2GB \\
\hline RAM & DDR4 16GB \\
\hline HDD & 1 TB \\
\hline SSD & $250 \mathrm{~GB}$ \\
\hline
\end{tabular}

TABLE 3

SPECIFICATION SOFTWARE

\begin{tabular}{ll}
\multicolumn{1}{c}{ Name } & \multicolumn{1}{c}{ Descriptions } \\
\hline Operating System & Windows 10 Pro 64-bit \\
\hline Anaconda Navigator & Version 4.4.10 \\
\hline Spyder & Version 3.2.6 \\
\hline Jupyter Notebook & Version 5.4.0 \\
\hline Python & Version 3.6.4 \\
\hline Android Studio & Version 3.2.1 \\
\hline
\end{tabular}

\section{Training}

The training process is a process to make the system learn the features that exist in the image and classify these features [19]. In this study using a dataset of corn disease images with a number of 3,854 images with types of diseases, namely Common Rust, Gray Leaf Spot, and Northern Leaf Blight.

TABLE 4

TRAINING DATASET

\begin{tabular}{ccccc}
\multicolumn{5}{c}{ TRAINING DATASET } \\
\hline $\begin{array}{c}\text { Data } \\
\text { Train }\end{array}$ & $\begin{array}{c}\text { Data } \\
\text { Test }\end{array}$ & $\begin{array}{c}\text { Time } \\
\text { Epoch }\end{array}$ & $\begin{array}{c}\text { Time } \\
\text { (minute) }\end{array}$ & Accuracy \\
\hline $20 \%$ & $80 \%$ & 50 & 135 & 0.9810 \\
\hline $40 \%$ & $60 \%$ & 50 & 107 & 0.9894 \\
\hline $50 \%$ & $50 \%$ & 50 & 94 & 0.9833 \\
\hline $60 \%$ & $40 \%$ & 50 & 107 & 0.9917 \\
\hline $80 \%$ & $20 \%$ & 50 & 134 & 0.9922 \\
\hline $20 \%$ & $80 \%$ & 100 & 270 & 0.9867 \\
\hline $40 \%$ & $60 \%$ & 100 & 215 & 0.9896 \\
\hline $50 \%$ & $50 \%$ & 100 & 195 & 0.9924 \\
\hline $\mathbf{6 0 \%}$ & $\mathbf{4 0 \%}$ & $\mathbf{1 0 0}$ & $\mathbf{2 1 5}$ & $\mathbf{0 . 9 9 6 4}$ \\
\hline $80 \%$ & $20 \%$ & 100 & 265 & 0.9964 \\
\hline
\end{tabular}

Table 4 shows a comparison of the amount of training data and testing data used for the training dataset in the Convolutional Neural Network model.

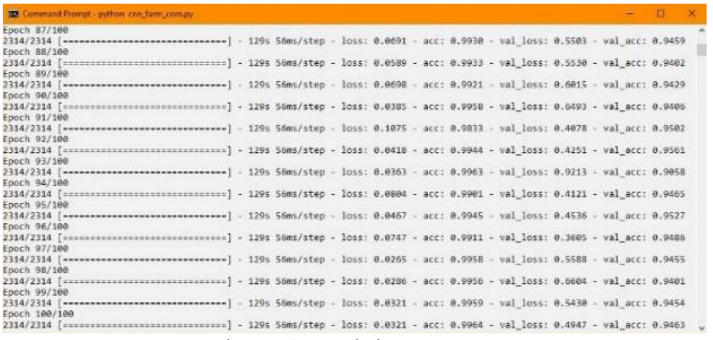

Figure 8. Training Dataset

In Figure 8. Shows the process of training the corn plant disease dataset with a comparison of training data of $60 \%$ and data testing by $40 \%$. With an epoch number of 100 epochs, with training time of 215 minutes. Get the accuracy of 0.9964 and the loss results are 0.0321 .

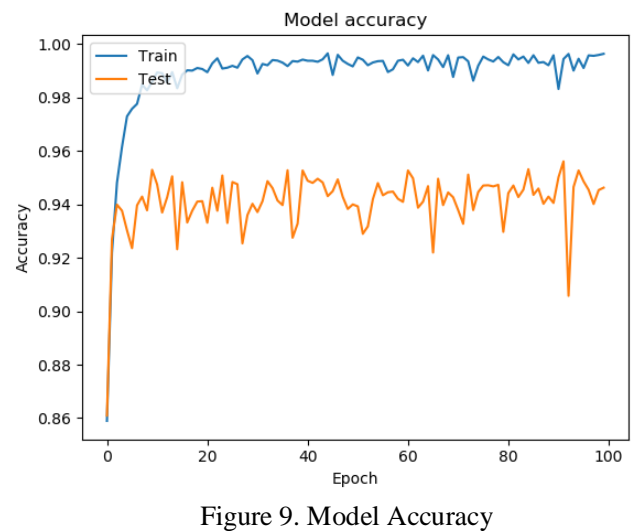

In figure 9. Shows the results of accuracy on the CNN model used, with accuracy results on the train at 0.9964 , while the accuracy on the model test is 0.9463 .

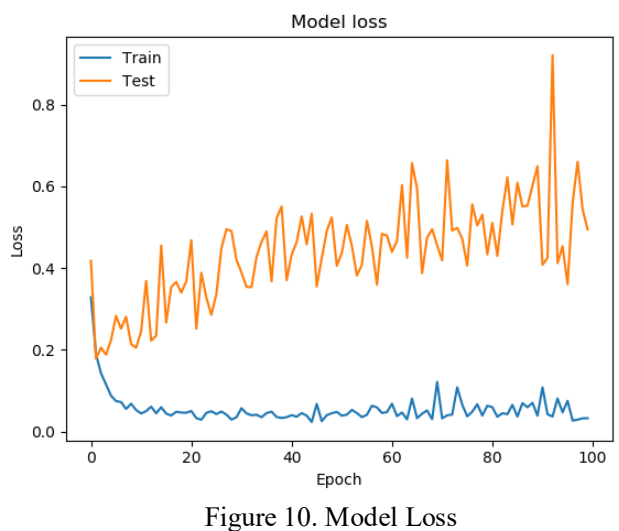

In Figure 10. The graph shows the loss results in the convolutional neural network model with the results of the loss on the train by 0.0321 , while the results of the loss in the test are 0.4947 . 


\section{Visualization Images}

The following is a visual display of images of corn plants at the time through the training and classification process in the Convolutinal Neural Network method.

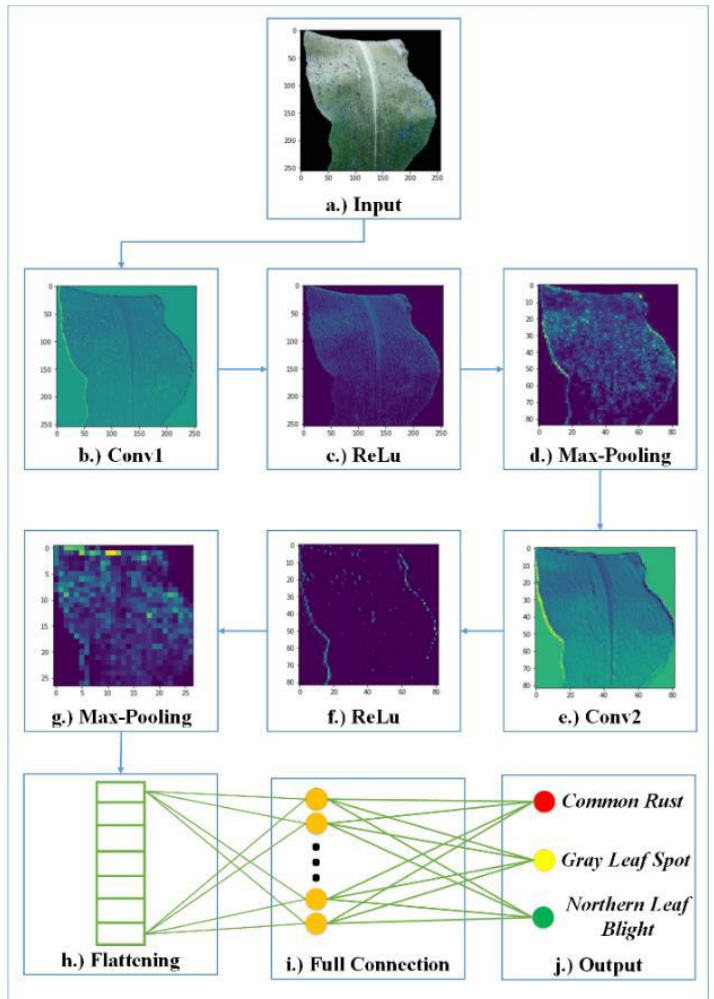

Figure 11. Visualization Images

\section{Implementation in the Mobile Application}

Implementation can be done using the application of android-based corn plant disease detection, by inputting disease images from the gallery than clicking the diagnostic button to send images to the server that will be diagnosed using the Convolutional Neural Network method, after the image upload process is complete the diagnosis is obtained.

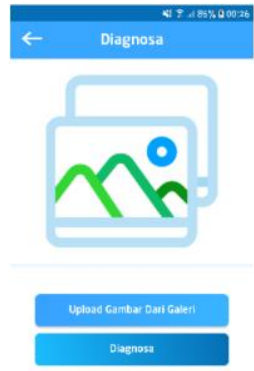

(a) Menu Diagnosis

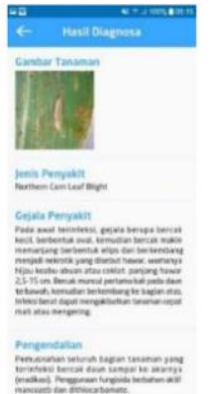

(b) Results Diagnosis
Figure 12. Diagnosis Process
In figure 12. Shows the process of implementing disease detection using a mobilebased application. In figure (a) shows the diagnostic menu that has two buttons, namely uploading images from the gallery and the diagnostic button that serves to upload the image. In figure (b) shows the results of the diagnosis in the form of pictures of the disease, name of the disease, symptoms of the disease, and control.

After the diagnosis process is complete, the user will get the results of the diagnosis in the form of pictures of diseases, types of diseases, symptoms of the disease, and control of diseases that attack the corn plants, as shown in Table 5.

TABLE 5

RESULTS DIAGNOSIS

Name
$\begin{aligned} & \text { Picture of the } \\ & \text { Disease }\end{aligned}$

\section{Testing}

In the research on corn plant disease detection using the Convolutional Neural Network method, a test was conducted to test the accuracy of the results of the classification of training data features with 100 maize disease data on each disease as shown in Table 6.

\begin{tabular}{lccc} 
& TABLE 5 & & \\
& TESTING & & \\
\hline \multicolumn{1}{c}{ Name Disease } & Data & True & False \\
\hline Common Rust & 100 & 93 & 7 \\
\hline Gray Leaf Spot & 100 & 92 & 8 \\
\hline Northern Leaf Blight & 100 & 96 & 4 \\
\hline
\end{tabular}

\section{Conclusion}

The Convolutional Neural Network method can be implemented for disease detection in corn plants. In the research on corn plant disease detection using the Convolutional Neural Network method has an accuracy of $99 \%$ in detecting maize plant diseases. 


\section{Jurnal Ilmu Komputer dan Informasi (Journal of Computer Science and Information),}

volume 12, issue 1, February 2019

\section{References}

[1] A. Kamilaris dan F. X. Prenafeta-Boldú, "Deep learning in agriculture: A survey," Computers and Electronics in Agriculture. 2018.

[2] M. Dyrmann, H. Karstoft, dan H. S. Midtiby, "Plant species classification using deep convolutional neural network," Biosyst. Eng., pp. 72-80, 2016.

[3] X. Zhang, Y. Qiao, F. Meng, C. Fan, dan M. Zhang, "Identification of maize leaf diseases using improved deep convolutional neural networks," IEEE Access, vol. 6, 2018.

[4] Y. Lu, S. Yi, N. Zeng, Y. Liu, dan Y. Zhang, "Identification of rice diseases using deep convolutional neural networks," Neurocomputing, 2017.

[5] Y. Sun, L. Zhu, G. Wang, dan F. Zhao, "MultiInput Convolutional Neural Network for Flower Grading," J. Electr. Comput. Eng., 2017.

[6] S. Zhang, W. Huang, dan C. Zhang, "Threechannel convolutional neural networks for vegetable leaf disease recognition," Cogn. Syst. Res., 2018.

[7] J. Ma, K. Du, F. Zheng, L. Zhang, Z. Gong, dan Z. Sun, "A recognition method for cucumber diseases using leaf symptom images based on deep convolutional neural network," Comput. Electron. Agric., 2018.

[8] M. Brahimi, K. Boukhalfa, dan A. Moussaoui, "Deep Learning for Tomato Diseases: Classification and Symptoms Visualization," Appl. Artif. Intell., 2017.

[9] K. P. Ferentinos, "Deep learning models for plant disease detection and diagnosis," Comput. Electron. Agric., 2018.

[10] S. Sladojevic, M. Arsenovic, A. Anderla, D. Culibrk, dan D. Stefanovic, "Deep Neural Networks Based Recognition of Plant Diseases by Leaf Image Classification," Comput. Intell. Neurosci., 2016.

[11] R. S. I Wayan Suartika E. P, Arya Yudhi Wijaya, "Klasifikasi Citra Menggunakan Convolutional Neural Network (Cnn) pada Caltech 101," J. Tek. ITS, vol. 5(1), 2016.

[12] J. Amara, B. Bouaziz, dan A. Algergawy, “A Deep Learning-based Approach for Banana Leaf Diseases Classification," 2017.

[13] J. Luo, S. Geng, C. Xiu, D. Song, dan T. Dong, "A curvelet-SC recognition method for maize disease," J. Electr. Comput. Eng., 2015.

[14] C. DeChant et al., "Automated Identification of Northern Leaf Blight-Infected Maize Plants from Field Imagery Using Deep Learning," Phytopathology, 2017.

[15] K. Zhang, Q. Wu, A. Liu, dan X. Meng, "Can deep learning identify tomato leaf disease?," $A d v$. Multimed., 2018.

[16] Sebastian Moncada. (2018, August. 27). The Ultimate Guide to Convolutional Neural Networks(CNN).Available:https://www.superdata science.com/the-ultimate-guide-to-convolutionalneural-networks-cnn/.

[17] Dekalb. Corn Diagnostic Guide. Available : https://www.aganytime.com/dekalb/tools/Pages/C orn-Diagnostic-Guide.aspx.

[18] M. Yasin Said, Soernartiningsih, A. Tenrirawe, A.M. Adnan, Wasmo Wakman, A. Haris Talanca, Syafruddin. Petunjuk Lapang Hama, Penyakit, Hara Pada Jagung. Badan Penelitian dan Pengembangan Pertanian. 2008.

[19] Tiara Shafira. 2018. Implementasi Convolutional Neural Network untuk Klasifikasi Citra Tomat Menggunakan Keras. Skripsi. Fakultas Matematika Dan Ilmu Pengetahuan Alam. Universitas Islam Indonesia: Yogyakarta.

[20] Tutut Furi Kusumaningrum. 2018. Implementasi Convolutional Neural Network (CNN) untuk Klasifikasi Jamur Konsumsi di Indonesia Menggunakan Keras. Skripsi. Fakultas Matematika Dan Ilmu Pengetahuan Alam. Universitas Islam Indonesia: Yogyakarta. 